\title{
Intra-Brics Trade intensities: An Analytical study
}

\author{
Prof.Kalpana Singh \\ Amity School of Economics, Amity University, Noida, UP, India
}

\begin{abstract}
Nearly 17 percent of the world's total commodity trade is accounted by BRICS countries. BRICS countries,categorised as leading emerging economies and political powers at the regional and international level, are causing changes in the architecture of international development cooperation. Keeping in view the increasing international importance of BRICS countries both economically and politically and increasing efforts by leaders of BRICS countries to enhance mutual trade and strengthen BRICS as a group financially and politically, one of the major objectives of present study is to find out how intense the trade is among BRICS countries so as to determine whether the value of trade among BRICS countries is greater or smaller than expected value on the basis of their importance in world trade. The share of BRICS countries in total world commodity trade has persistently increased from 7.33\% in 2001 to17.25\% in 2015. During 2001-2015, intraBRICS trade as percent of Total BRICS trade is almost doubled, increasing from 6.03 to 12.12. However it is worth mentioning that China is the dominant contributor in both cases. Out of total BRICS share in world trade (17.25), 12.08 percent is accounted by China only. India's share is just 2\% while Brazil, Russia and South Africa have only $1.11,1.56$ and $0.51 \%$ share in world trade. Further, the findings of the present study also reveals that the Intra-BRICS trade of major BRICS countries (China, India and Russia) became less intense as intra-BRICS trade intensities decreased in 2015 compared to that in 2001. Intra-BRICS trade intensity of BRICS as a group decreased from 0.82 in 2001 to 0.70 in 2015 . For India and Russia it is 0.84 and 0.85 respectively and for China, it is just 0.59 in 2015, implying that China's trade with other BRICS countries is far less than expected, given its importance in world trade. However for Brazil and South Africa, trade flows between these two countries and other BRICS countries is more than expected given their importance in world trade, as the figures for intra-BRICS trade intensity are greater than one.
\end{abstract}

Keywords -BRICS, Export Intensity Index, Import Intensity Index, Intra-BRICS Trade, Trade Intensity Index

\section{INTRODUCTION}

Originally the term BRIC was coined by Mr Jim O’Neill of Goldman Sachs, in 2001, to refer to Brazil, Russia, India and China as the countries from whom it was expected that much of the world's economic growth would come. Forecasts were made that these emerging economies would realise fast economic growth and be larger than some of the developed economies [1].This group officially became a diplomatic-political entity in 2006, and a regular informal diplomatic coordination was initiated by these four countries with annual meetings of Foreign Ministers at the margins of the General Debate of the UN General Assembly (UNGA). As a result of this successful interaction, need was felt for a dialogue to be carried out at the level of Heads of State and Government in annual Summits[2].In BRIC, initially, there was no African country but in 2010, with inclusion of South Africa, BRIC came to be known as the BRICS [3].

Uptill now seven Summits have already been held. First summit held in Yekaterinburg in 2009 and the latest (seventh) was held in the Russian city of Ufa in Bashkortostan on 8-9 July 2015. The 2016 BRICS summit has been scheduled to be held in Panaji, Goa in India, from 15th to 16th October 2016. It will be the eighth annual BRICS summit, an international relations conference which is to be attended by the heads of state or heads of government of the five member states Brazil, Russia, India, China and South Africa.From February, 2016 to December, 2016, India will play its role in the capacity as chair of BRICS [4].

\subsection{BRICS in Global Economy}

The five countries comprising BRICS, represent 3 billion people and have combined GDP of 16 trillion dollars[5].Nearly 17 percent of the world's total commodity trade is accounted by BRICS countries.BRICS representing 42 percent of the world's population, contributes roughly 20 percent of the world's economy based on Gross Domestic Product (GDP) and 30 percent of the world's GDP based on Purchasing Power Parity (PPP)[6]. The BRIC grouping is predicted to account for a third of the global economy (in PPP terms) and to contribute about $49 \%$ of global GDP growth by 2020. By 2050, Most of the current G-7 countries would be 
displaced by Brazil,Russia, India and China. Only the United States and Japan are expected to be counted amongst the largest economies of the world. The BRICs are clearly moving from the bantam-weight to the heavy-weight category [7].

BRICS countries categorised as leading emerging economies and political powers at the regional and international level, are causing changes in the architecture of international development cooperation. This is not only with regard to trade and financial flows but also as emerging donors [8].

The major characteristics on the basis of which countries' group is distinguished are[9]:

1. The outstanding size of their economies,

2. Strong growth rates, leading to increasing significance in world economy

3. The demand for a stronger political voice in international governance structures corresponding to their economic status

The most important aspect that highlights the relevance of the BRICS group might be their quest for higher representation and political say in global governance. The countries of BRICS, the US and the EU (European Union) have mutual economic interests and interdependencies. Their political strategy thus targets multilateral negotiation and cooperation rather than confrontation and power politics. Taking into account, the BRICS countries' respective trade in goods and services, their capital flows and foreign direct investment (FDI), it is very likely that the focal point of global economic dynamics might shift slowly towards the BRICS in coming years. BRICS are also assuming importance as donors in the international financial architecture [8].

The launch of New Development Bank (NDB) by BRICS in Shanghai in July 2015 to finance infrastructure and "sustainable development" projects and creation of $\$ 100$ billion Contingent Reserve Arrangement (CRA), to tide over members in financial difficulties are landmarks in the history of the BRICS grouping. They are seen as more responsive alternatives to institutions such as the World Bank and the IMF [10].

Role of BRICS countries in the world economy in terms of total production, receiving investment capital, and expanding potential consumer markets is vital and these economies have been widely regarded as the engines of the global economic recovery,

In view of this it is expected that BRICS countries develop pragmatic economic cooperation and forge closer economic partnership in order to contribute to promoting global economic recovery, reduce potential risks in the international financial markets and increase economic growth among its members [11]. Trade and investment is one of the priority areas for cooperation among BRICS countries. Therefore, if there takes place a more active intra-BRICS trade and investment cooperation, it will contribute to economic growth.It will also help in utilising the use of existing opportunities of BRICS economic complementarity and would further strengthen the positions of the Member States in the global economy and contribute to achieving sustainable, inclusive and dynamic growth [11].

\subsection{Review of Literature}

Several studies have been undertaken in the field of measuring trade intensities of partner countries or intra-trade intensity of particular regional integrations. Few of the studies are summarised as below:

A study by Maxwell Ekor, Jimoh Saka and OluwatosinAdeniyi(2015), titled Trade Intensity Analysis of South Africa-BRIC Economic Relations, focused on examining the trade and investment relationship of South Africa with the BRIC. The study used both descriptive and vector autoregressive estimation approaches. The main objective was to investigate the impact of trade shocks between South Africa and the individual member countries of the BRIC bloc. The findings of the study suggest that in the review period, South Africa's trade intensity was more with India followed by trade with China. The findings in respect of impulse-response outcome indicated that South Africa's GDP reverts faster to equilibrium in case of a shock in exports to and imports from Brazil. It concludes that South Africa showed considerable trade intensity with most BRIC Countries. Policy implications are that South Africa can benefit substantially from policies which target at broadening the scope of its international trade relations with the BRIC bloc with special emphasis on Brazil and China[12].

In an another study, titled 'Trade intensity and business cycle synchronization: East Asia versus Europe', PradumnaBickram Rana a, Tianyin Cheng b and Wai-Mun Chia b makes a comparative analysis of the relationship of trade intensities with synchronization of business cycles in East Asia and Europe. The findings of the study suggest that intra-industry trade, and not the inter-industry trade, is the major factor that explains business cycle co-movements in both regions[13]

A case study by PradeepaDembatapitiya (2013), on Trade Flow and Determinants of Trade Intensity in South Asian Region, focuses on the way, South Asian members direct their bilateral trade andthe determinantsof trade intensity between two nations. The study also attempts to find out whether trade agreements and export market diversification significantly influence on intense trade. The study used Gravity model analysis by setting "Trade Intensity" as response variable. The findings of the study suggest that in determining the trade intensity 
of South Asia, export market diversification becomes a key factor. The effect of Trade agreements on trade intensity has also found to be positive and significant. Though complementary index of some trading partners in the region is high, trade between them is at significantly low level[14].

Another study by Silva, Valquiria da, Anefalos, Lilian C., \& R. Filho, José Carlos G. dos. (2003) tries to identify the component of trade resulting specifically from bilateral relations and to evaluate the effects of creation of trading blocs on trade relations between countries. The trirapport coefficient of the relative intensity of bilateral agricultural sector trade flows between Brazil and other countries from 1984 and 1998 is used in the evaluation. In general, the results show that relative trade intensity between Brazil and its non-MERCOSUL trade partners fell after their entry into regional trade agreements (extra-bloc effect). The intra-bloc effect (trade expansion) is reflected by changes in trade intensity between Brazil and the other MERCOSUL members and changes in trade intensity between NAFTA members Mexico, Canada, and the United States[15].

\subsection{Objectives of the study}

The major objectives of present study are:

(i) To examine the trends in Share of BRICS as a group and of individual countries of BRICS in World trade during 2001-2015

(ii) to analyse trends in the Intra-Brics Trade intensity of BRICS as a group during the time period 20012015

(iii) to analyse the trends in the Intra-BRICS trade intensity of each of the BRICS Countriesduring the time period 2001-2015

\section{$1.4 \quad$ Methodology}

The present study is based on secondary data and information collected from a variety of sources. The major source of data is International trade statistics from online data base of International Trade Centre. To analyse Intra-Brics Trade intensity of BRICS as a group, trade intensity measures have been used. These measures are used to determine whether the value of trade between two countries is greater or smaller than expected value on the basis of their importance in world trade. Trade intensity of Intra-BRICS trade as a group has been measured separately for intra-BRICS exports, intra-BRICS imports and intra-BRICS total trade. Export Intensity Index(EII) is defined as the ratio of a trading partner's share to a country/region's total exports and the share of world exports going to the same trading partner. It is calculated as:

$\mathrm{XII}_{\mathrm{ij}}=\left(\mathrm{xij} / \mathrm{X}_{\mathrm{iw}}\right) /\left(\mathrm{x}_{\mathrm{wj}} / \mathrm{Xww}\right)$

wherexij is the dollar value of exports of country/region $i$ to country/region $\mathrm{j}$, Xiw is the dollar value of the exports of country/region $i$ to the world, $x w j$ is the dollar value of world exports to country/region $\mathrm{j}$, and Xww is the dollar value of world exports. An index of more than one indicates that trade flow between countries/regions is larger than expected given their importance in world trade[16]. Import Intensity Index (MII) is defined as the ratio of a trading partner's share to a country/region's total imports and the share of world imports from the same trading partner. It is calculated as:

$$
\mathrm{MII}_{\mathrm{ij}}=\left(\mathrm{mij} / \mathrm{M}_{\mathrm{iw}}\right) /\left(\mathrm{m}_{\mathrm{wj}} / \mathrm{Mww}\right)
$$

Where $m_{i j}$ is the dollar value of imports of country/region i from country/region $\mathrm{j}$, Miw is the dollar value of the imports of country/region $\mathrm{i}$ from the world, $\mathrm{x}_{\mathrm{wj}}$ is the dollar value of world imports from country/region j, and Mww is the dollar value of world imports. Finally Intra-regional (Intra-BRICS in present study) trade intensity index is the ratio of intra-regional trade share to the share of world trade with the region, calculated using trade data. It is computed as:

$\mathrm{TII}_{\mathrm{ii}}=\left(\mathrm{T}_{\mathrm{ij}} / \mathrm{T}_{\mathrm{i}}\right) /\left(\mathrm{T}_{\mathrm{i}} / \mathrm{T}_{\mathrm{w}}\right)$

whereTij is exports of region $\mathrm{i}$ to region $\mathrm{j}$ plus imports of region $\mathrm{i}$ from region $\mathrm{j}$; $\mathrm{Ti}$ is total exports of region i to the world plus total imports of region i from the world; and Tw is total world exports plus imports. It determines whether trade within the region is greater or smaller than should be expected on the basis of the region's importance in world trade. An index of more than one indicates that trade flow within the region is larger than expected given the importance of the region in world trade[16].

All three indices have also been measured in respect of each of the individual countries of BRICS.

Compound Annual Growth Rates of Intra Brics trade have also been calculated, to compare rates of growth of exports and imports of total commodity trade in one country/region with those for world trade or the trade of its competitors. For most of the work done in this paper, major source of information is International Trade Statistics available on online data base of International Trade Centre.

\section{MAJOR TRENDS IN BRICS TRADE}




\subsection{Trends in share of BRICS in World Trade (2001-2015)}

As shown in table-1 and Figure-1, the share of BRICS countries in total world commodity trade has persistently increased during 2001-2015. During 2001 to 2015 it is more than doubled, increasing from 7.33\% to17.25\%. However during 2013-15, the increase has been very less. The major contribution came from China whose share in world trade was lessthan $4.10 \%$ in 2001, but rose to $12.08 \%$.in 2015(Figure 2 \&AnnexureI). India accounted just $2 \%$ of World trade in commodities compared to less than one percent in 2001. Shares of Brazil, Russia and South Africa also increased slightly during the period 2001-2015as shown in Figure -2 and Annexure-I.

As reflected in Table-1 and Figure-1, BRICS'percentage shares, as a group, in World Exports and Imports were 19.31 and 15.21respectively in 2015 whereas in 2001, these shares were 8.08 and 6.60. Again major contributor is China in respect of both exports and imports in most of the years during 2001-2015, as shown in Annexure-I.

Table-1 Share of BRICS Exports(X), Imports (M)and Total Trade(X+M) in World Exports, World imports and World Trade $(\mathrm{X}+\mathrm{M})$

\begin{tabular}{|c|c|c|c|}
\hline Year & $\begin{array}{l}\text { Share of BRICS Exports } \\
\text { in world Exports }\end{array}$ & $\begin{array}{l}\text { Share of BRICS Imports } \\
\text { in World Imports }\end{array}$ & $\begin{array}{l}\text { Share of BRICS Trade } \\
\text { in World Trade }\end{array}$ \\
\hline 2001 & 8.08 & 6.60 & 7.33 \\
\hline 2002 & 8.84 & 7.17 & 7.99 \\
\hline 2003 & 9.86 & 8.14 & 8.99 \\
\hline 2004 & 10.87 & 9.02 & 9.93 \\
\hline 2005 & 12.27 & 9.69 & 10.97 \\
\hline 2006 & 13.24 & 10.35 & 11.78 \\
\hline 2007 & 14.11 & 11.17 & 12.62 \\
\hline 2008 & 14.73 & 12.08 & 13.39 \\
\hline 2009 & 15.33 & 12.97 & 14.13 \\
\hline 2010 & 16.44 & 14.62 & 15.52 \\
\hline 2011 & 16.91 & 15.41 & 16.15 \\
\hline 2012 & 17.36 & 15.86 & 16.61 \\
\hline 2013 & 18.02 & 16.23 & 17.12 \\
\hline 2014 & 18.29 & 15.94 & 17.12 \\
\hline 2015 & 19.31 & 15.21 & 17.25 \\
\hline
\end{tabular}

Source: Compiled and Computed by the author basedonInternational Trade Centre, (ITC)database, Trade by Commodity Statistics 2001-2015[17].

Figure-1 Share of BRICS Exports(X), Imports (M)and Total Trade(X+M) in World Exports, World imports and World Trade $(\mathrm{X}+\mathrm{M})$

\section{Chart Title}

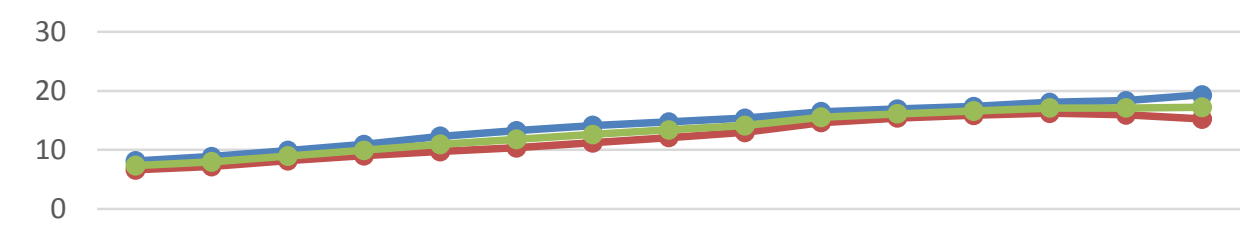

200120022003200420052006200720082009201020112012201320142015

- Share of BRICS Exports in world Exports

- Share of BRICS Imports in World Imports

- Share of BRICS Trade in World Trade

Source:Author's compilation based on Table-1 
Figure-2 Share of BRICS countries in World Trade (Commodities)

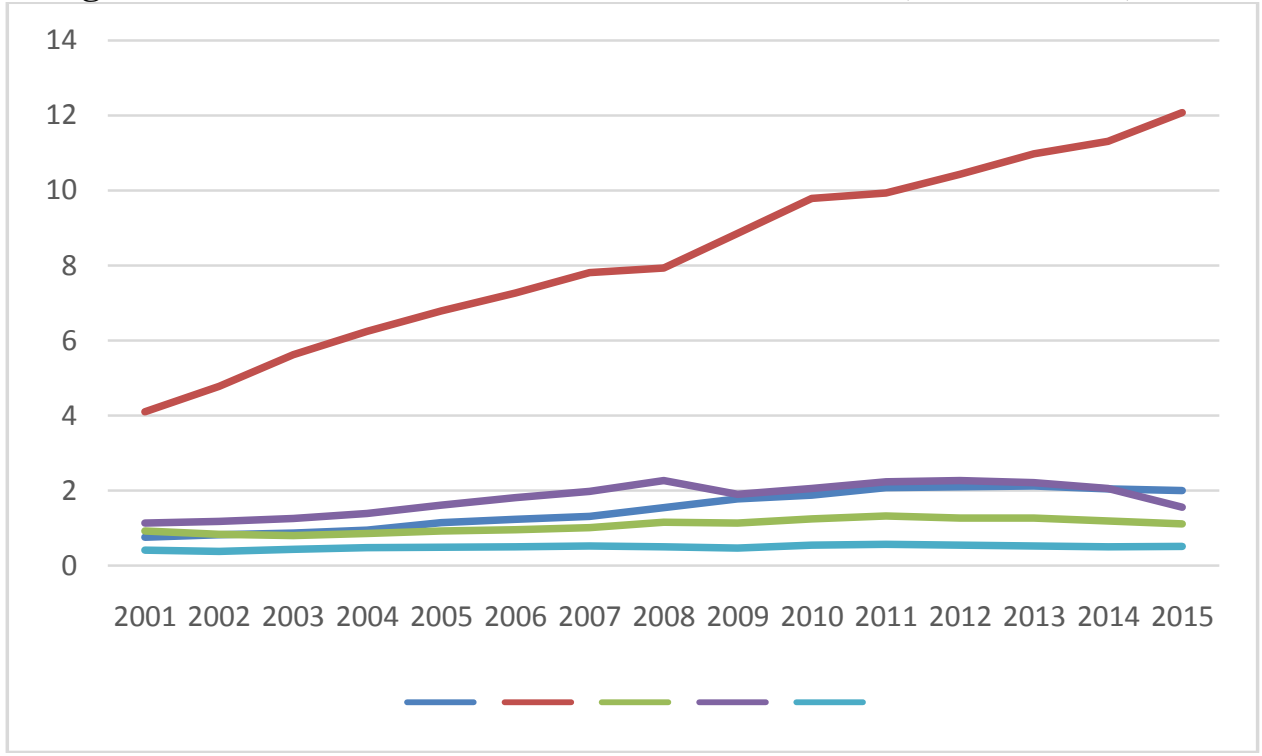

Source:Author's compilation based on Annexure-1

\subsection{Share of Intra-BRICS trade in Total BRICS trade} in Table-2.

The figures for percentageshare of Intra-BRICS Trade in total BRICS trade from World are presented

Table-2Share of Intra-BRICS Trade in total BRICS trade

\begin{tabular}{|c|c|c|c|}
\hline Year & $\begin{array}{l}\text { Share of Intra-BRICS } \\
\text { Exports in Total BRICS } \\
\text { exports }\end{array}$ & $\begin{array}{l}\text { Share of Intra- BRICS } \\
\text { Imports in Total BRICS } \\
\text { Imports }\end{array}$ & $\begin{array}{l}\text { Share of Intra- } \\
\text { BRICS Trade in Total } \\
\text { BRICS Trade }\end{array}$ \\
\hline 2001 & 4.27 & 8.12 & 6.03 \\
\hline 2002 & 4.72 & 9.50 & 6.89 \\
\hline 2003 & 5.13 & 10.55 & 7.62 \\
\hline 2004 & 5.22 & 11.52 & 8.13 \\
\hline 2005 & 5.69 & 13.20 & 9.05 \\
\hline 2006 & 5.87 & 14.02 & 9.50 \\
\hline 2007 & 6.62 & 14.99 & 10.37 \\
\hline 2008 & 7.18 & 15.31 & 10.89 \\
\hline 2009 & 7.61 & 15.94 & 12.48 \\
\hline 2010 & 8.51 & 15.93 & 12.03 \\
\hline 2011 & 8.92 & 16.30 & 12.67 \\
\hline 2012 & 8.78 & 16.89 & 12.51 \\
\hline 2013 & 8.69 & 16.75 & 12.24 \\
\hline 2014 & 8.50 & 16.53 & 12.12 \\
\hline 2015 & 7.74 & 17.62 & \\
\hline
\end{tabular}

Source:Compiled and Computed by the author based on International Trade Centre, (ITC) database, Trade by Commodity Statistics 2001-2015[17] 


\section{Figure-3Share of Intra-BRICS Trade in total BRICS trade}

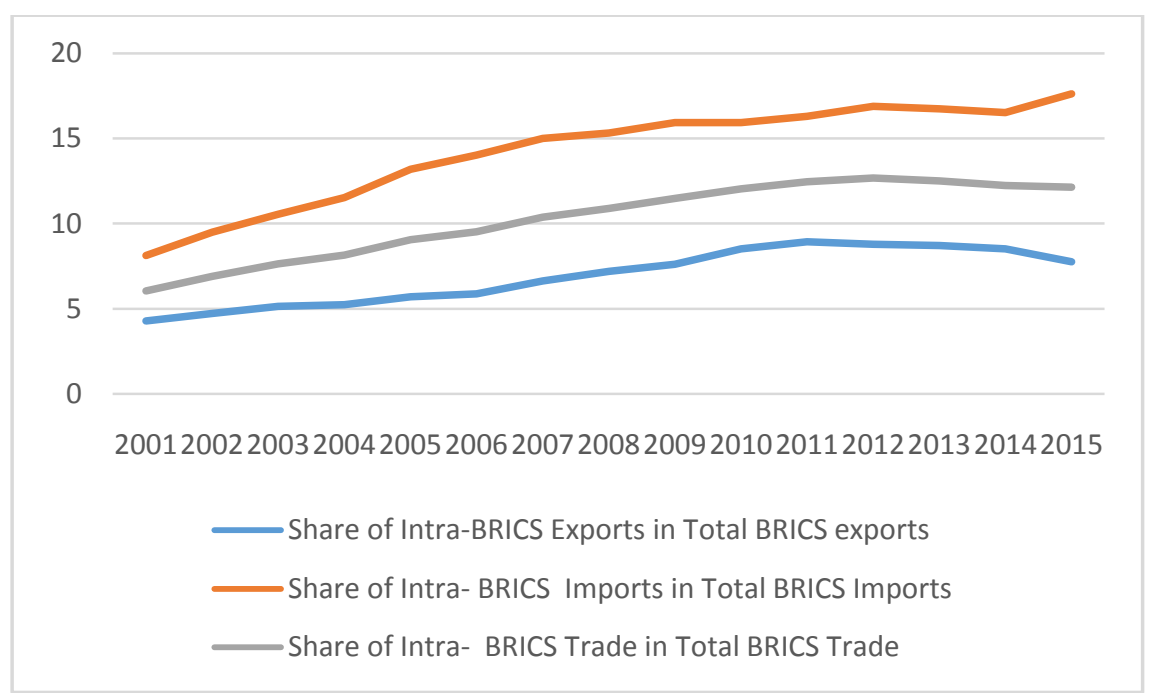

Source: Author's compilation based on Table-2

As shown in Table-2 and figure-3, Intra-BRICS trade as percent of total BRICS trade is more than doubled during 2001-2015 however share of intra-BRICS imports has been much higher than share of intraBRICS exports in all years during the period of study. It is also worth mentioning that the increase in IntraBRICS trade as percent of total BRICS trade is the least during 2010-2015(.09 percentage points), compared to 2001-2005 (3.02 percentage points) and 2005-2010(2.98 percentage points). From 2012 to 2014,it decreased.

\subsection{Compound Annual Growth Rates}

Table 3 presents the compound annual growth of various aspects of BRICS trade. Although the intraBRICS trade increased at CAGR of $20 \%$ and total BRICS Trade from the world at CAGR of $13.93 \%$ during 2001-2015, yet the share of Intra -BRICS Trade in total BRICS trade from world increased at a lesser rate(5.11 percent) than the share of BRICS trade with world in Total world trade(6.31 percent).

\section{Table-3 Compound Annual Growth Rates, CAGR (2001-2015) of BRICS Commodity Trade}

\begin{tabular}{|l|c|}
\hline BRICS exports, imports and Trade & CAGR (percent), 2000-2014 \\
\hline Total Intra-BRICS Exports & 19.11 \\
\hline Total Intra-BRICS Imports & 20.13 \\
\hline Total Intra-BRICS Trade(X+M) & 20.0 \\
\hline Total BRICS Exports to World & 14.15 \\
\hline Total BRICS Imports from the World & 13.66 \\
\hline Total BRICS Trade(X+M) from the World & 13.93 \\
\hline Total World Exports & 7.27 \\
\hline Total World Imports & 7.08 \\
\hline Total World Trade $(X+M)$ & 7.17 \\
\hline Total Intra -BRICS Trade/Total BRICS Trade from World & 5.11 \\
\hline Total World Trade with BRICS/Total World Trade & 6.31 \\
\hline
\end{tabular}

Source:Compiled and Computed by the author based on International Trade Centre, (ITC) database, Trade by Commodity Statistics 2001-2015[17]

\section{INTRA-BRICS TRADE INTENSITY}

Keeping in view the increasing international importance of BRICS countries both economically and politically and increasing efforts by leaders of BRICS countries to enhance mutual trade and strengthen BRICS as a group financially and politically, one of the major objectives of present study is to find out how intense the 
trade is among BRICS countries so as to determine whether the value of trade among BRICS countries is greater or smaller than expected value on the basis of their importance in world trade. As mentioned in Methodology section, the present study has measured Intra-BRICS Export intensity index(XII), Intra-BRICS Import intensity index(MII), and Intra-BRICS Trade intensity index (TII) for the BRICS as a group and for each of the BRICS countries. Sections 3.1 has been devoted to the analysis of Intra-BRICS Trade intensity indices for the BRICS as a group while section 3.2 focuses on analysis of Intra-BRICS Trade intensity indices of individual countries of BRICS.

\subsection{Intra-BRICS Trade intensity of BRICS as a group}

The following expressions have been used to measure XII, MII and TII for the BRICS as a group:

$$
\mathrm{XII}_{\mathrm{bb}}=\left(\mathrm{x}_{\mathrm{bb}} / \mathrm{X}_{\mathrm{bw}}\right) /\left(\mathrm{x}_{\mathrm{wb}} / \mathrm{Xww}\right)
$$

Where $\mathrm{x}_{\mathrm{bb}}$ is the dollar value of exports of BRICS countries to BRICS, $\mathrm{X}_{\mathrm{bw}}$ is the dollar value of the total exports of BRICS to the world, xwb is the dollar value of world exports to BRICS, and Xww is the dollar value of world exports.

$$
\mathrm{MII}_{\mathrm{bb}}=\left(\mathrm{mbb} / \mathrm{M}_{\mathrm{bw}}\right) /\left(\mathrm{m}_{\mathrm{wb}} / \mathrm{Mww}\right)
$$

Wherem $_{b b}$ is the dollar value of imports of BRICS countries from BRICS, $\mathrm{M}_{\mathrm{bw}}$ is the dollar value of the total imports of BRICS from the world, $\mathrm{m}_{\mathrm{wb}}$ is the dollar value of world imports from the BRICS, and Mww is the dollar value of world imports.

$$
\mathrm{TII}_{\mathrm{bb}}=\left(\mathrm{T}_{\mathrm{bb}} / \mathrm{T}_{\mathrm{b}}\right) /\left(\mathrm{T}_{\mathrm{b}} / \mathrm{T}_{\mathrm{w}}\right)
$$

whereTbb is exports of BRICS countries to BRICS plus imports of BRICS countries from BRICS; Tb is total exports of BRICS to the world plus total imports of BRICS from the world; and Tw is total world exports plus imports.

Despite the fact that intra-BRICS exports, imports and total trade has increased at a compound annual growth rate of 19.11,20.13 and 20 percent respectively during 2001-2015, the Intra-BRICS Export Intensity Index, Import Intensity Index and Trade Intensity Index show a declining trend during 2001-2015. Compared to 2001, The XII,MII and TII decreased in 2015 by .13, .12 and .12 percentage points respectively, as shown in Table -4 and Figure-4. Actually during the period of study, the CAGR of total world trade with BRICS as a ratio of total world trade(6.31) has been greater than the CAGR of total intra -BRICS trade as a ratio of total BRICS trade from World(5.11), as shown in Table-3.

Table-4 Trade intensities of Intra-BRICS Trade

\begin{tabular}{|l|l|l|l|}
\hline Year & XII & MII & TII \\
\hline 2001 & 0.63 & 1.04 & 0.82 \\
\hline 2002 & 0.64 & 1.11 & 0.86 \\
\hline 2003 & 0.61 & 1.10 & 0.85 \\
\hline 2004 & 0.56 & 1.09 & 0.82 \\
\hline 2005 & 0.57 & 1.10 & 0.83 \\
\hline 2006 & 0.55 & 1.09 & 0.81 \\
\hline 2007 & 0.58 & 1.09 & 0.82 \\
\hline 2008 & 0.58 & 1.06 & 0.81 \\
\hline 2009 & 0.57 & 1.06 & 0.81 \\
\hline 2010 & 0.57 & 0.99 & 0.78 \\
\hline 2011 & 0.57 & 0.98 & 0.77 \\
\hline 2012 & 0.55 & 0.98 & 0.76 \\
\hline 2013 & 0.54 & 0.93 & 0.73 \\
\hline 2014 & 0.53 & 0.91 & 0.72 \\
\hline 2015 & 0.50 & 0.92 & 0.70 \\
\hline
\end{tabular}

Source:Compiled and Computed by the author basedonInternational Trade Centre, (ITC)database, Trade by Commodity Statistics 2001-2015[17]

Because of similarity in consumer preferences, comparable per capita income, and often complementarities of resource endowment, there exists the huge trade (and investment) potential among BRICS countries[19], but the intra-regional trade among BRICS countries, though increasing over time, is just 12 percent of their total trade. 
Figure-4Intra-BRICS Export Intensity Index, Import Intensity Index and Trade Intensity Index

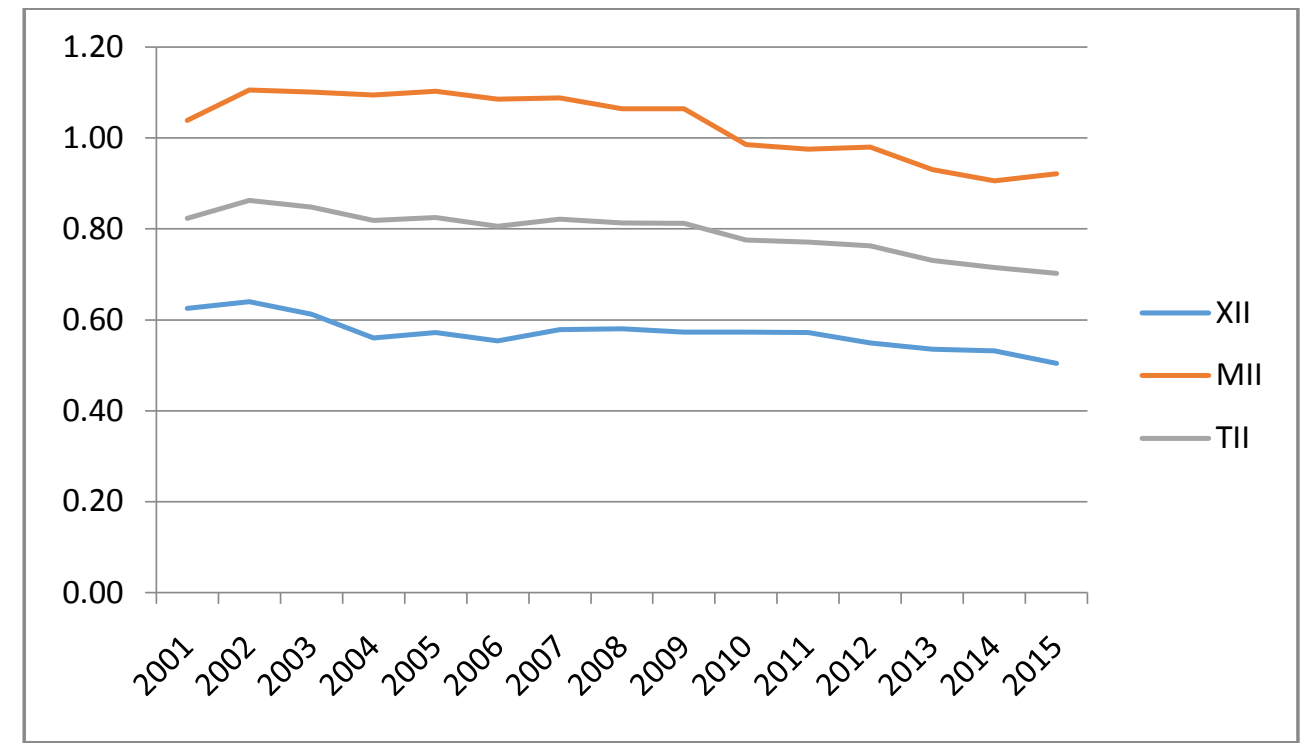

Source: Compiled by Author based on Table-4

\subsection{Intra-BRICS Trade intensity indices of BRICS countries}

Annexure-II and Figures-5, 6 and 7showIntra-BRICS Export Intensity Index, Import Intensity Index and Trade Intensity Index of each of the five countries of BRICS. As the data presented in Table-1 reveals that more than 17 percent of world trade is accounted by BRICS but so far as trade among BRICS countries is concerned the study finds that intra-BRICS trade is just 12.12 percent of total BRICS trade with the world. As a result the intensity of intra-BRICS trade of major BRICS Countries (China, India and Russia)decreased during 2001-2015. In case of India, the intra-BRICS trade intensity is 0.84 in 2015 and for china it is just 0.59 implying that trade flow between China and other BRICS countries is far less than expected, given its importance in world trade. However for Brazil and South Africa, the figures for intra-BRICS trade intensity are greater than one showing that trade flows between these two countries and other BRICS countries is more than expected given their importance in world trade.

\section{Figure-5Export intensity Indices of BRICS Countries}

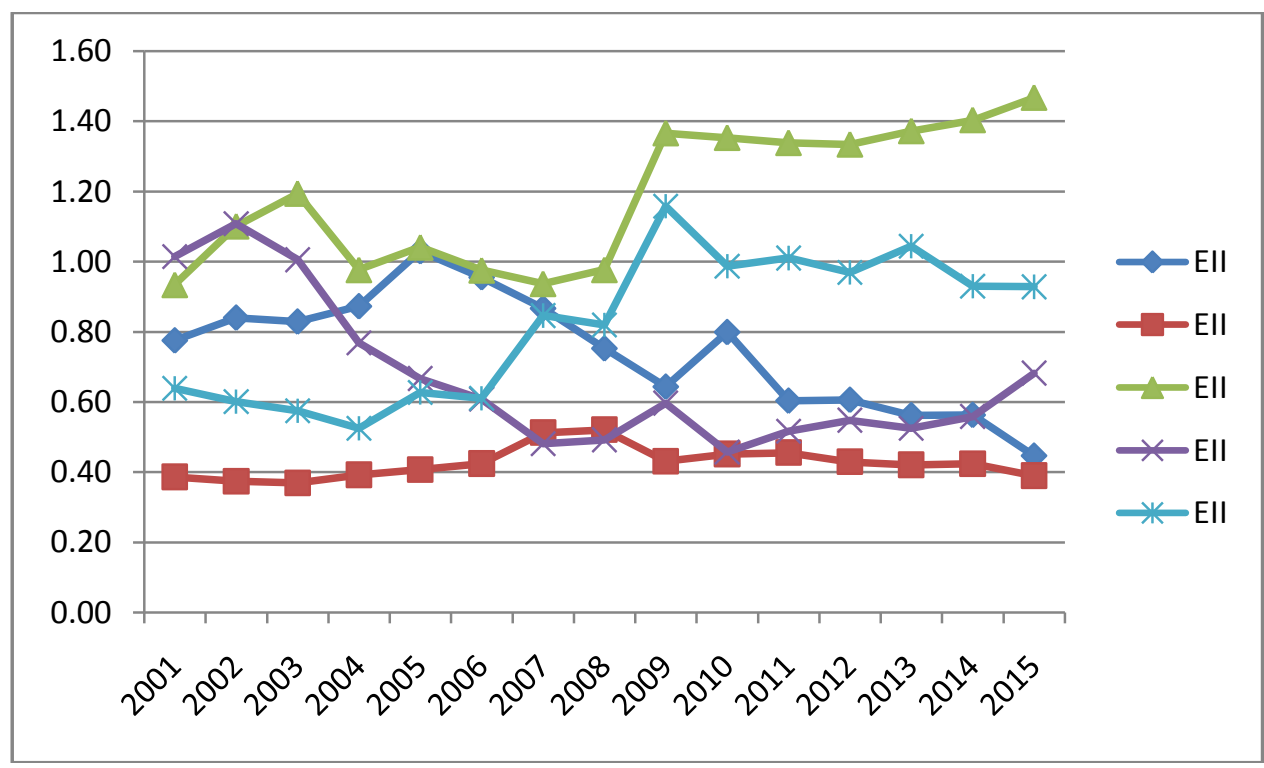


Source: Compiled by Author based on Annexure-II Figure-6 Import intensity Indices of BRICS Countries

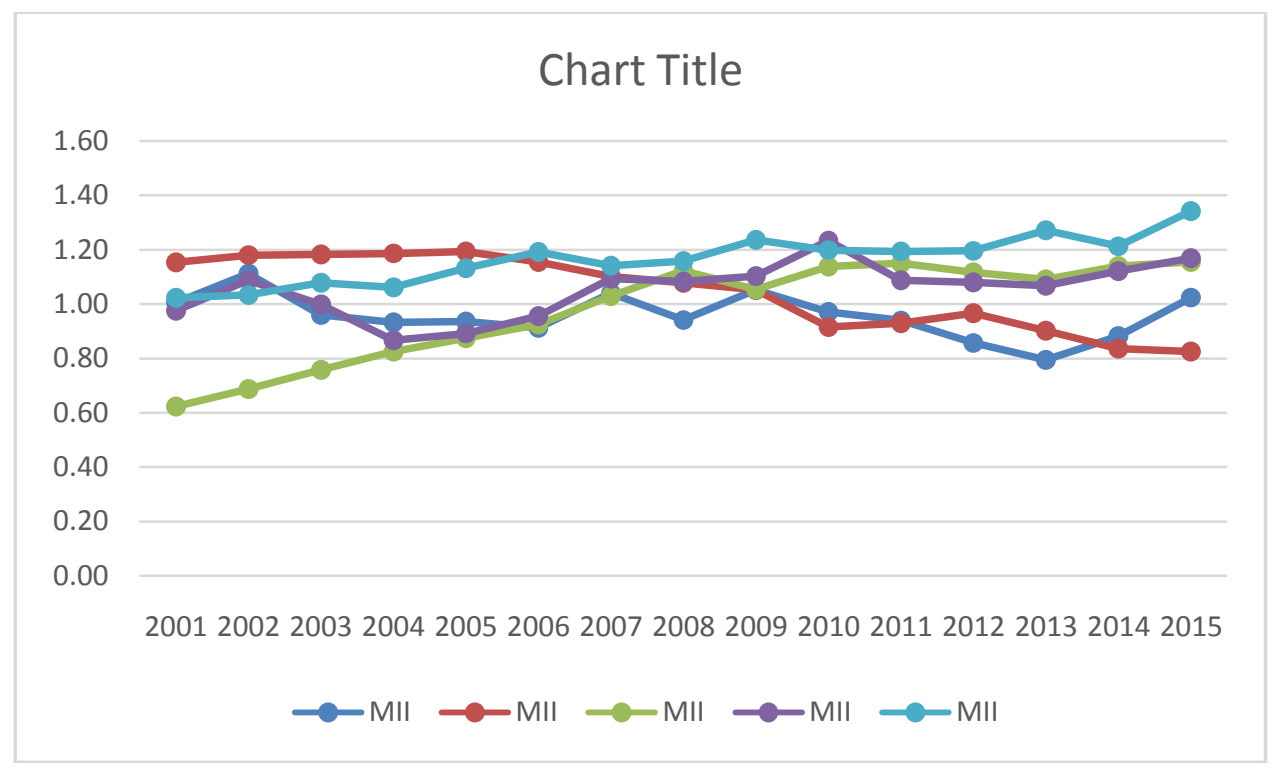

Source: Compiled by Author based on Annexure-II

Figure-7Trade intensity Indices of BRICS Countries

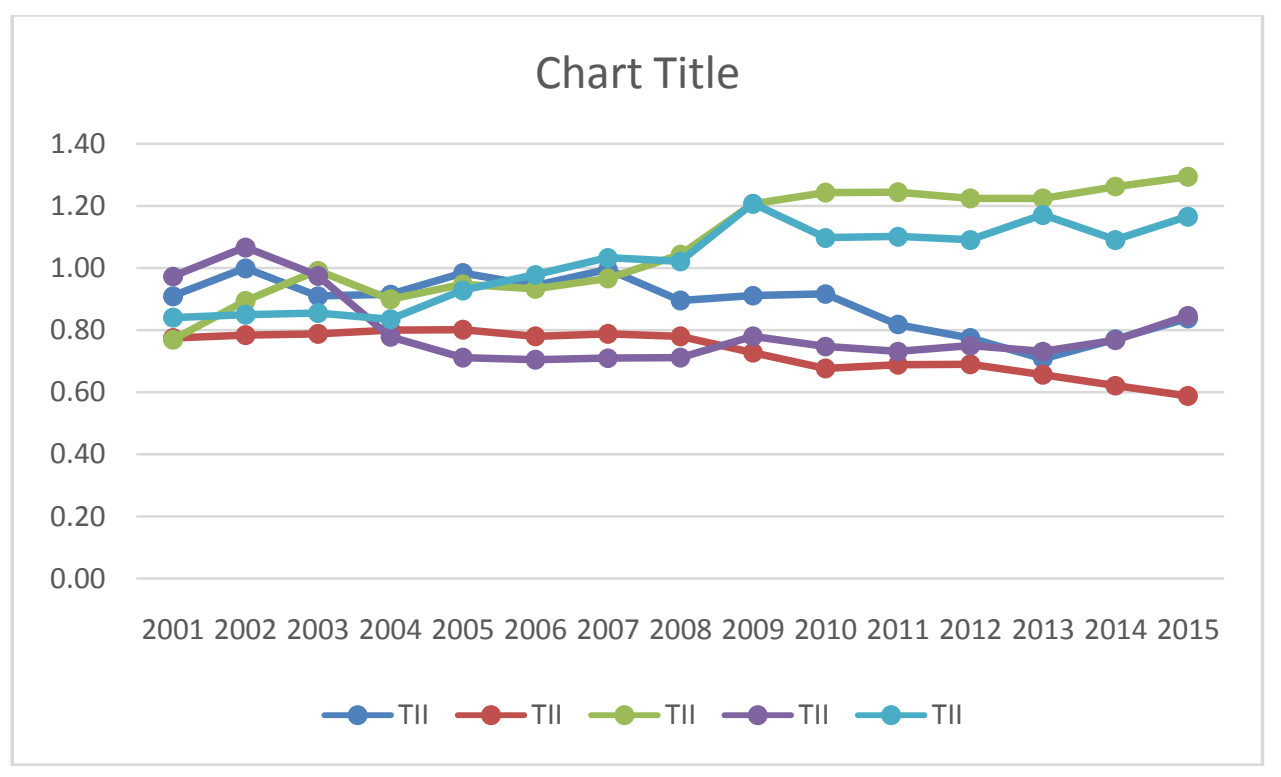

Source: Compiled by Author based on Annexure-II

IV. IV. CONCLUSION

When the term BRIC was coined in 2001 by Mr Jim O’Neill of Goldman Sachs, the Brazil, Russia, India and China were viewed as the countries from whom much of the world's economic growth was expected to come. The economies of these countries were forecasted to realise fast economic growth and be larger than some of the developed economies. It was also forecasted by Goldman Sachs, that the United States would be the only Western power to make it into the top five [18]. Projections made about BRICS grouping pose a very optimistic picture about BRICS role in global economy. The share of BRICS countries in total world commodity trade has persistently increased during 2001-2015. During 2001 to 2015 it is more than doubled, increasing from 7.33\%to $17.25 \%$.So far as trade among BRICS Countries is concerned, it has increased over time. During 2001-2015, intra-BRICS trade as percent of Total BRICS trade is almost doubled, increasing from 6.03 to 12.12. 
However it is worth mentioning that China is the dominant contributor in both cases. Out of total BRICS share in world trade (17.25), 12.08 percent is accounted by China only. India's share is just $2 \%$ while Brazil, Russia and South Africa have only 1.11, 1.56 and $0.51 \%$ share in world trade. In 2014, China accounted for more than fifty percent (51.4) of intra-BRICS exports and 43.34 percent of intra-BRICS imports [1].The present study mainly focused on examining the intra-BRICS trade intensities of BRICS as a group and that of individual BRICS countries. The findings of the study indicates that in spite of the fact that the Compound annual growth rates of intra-BRICS exports, imports and total trade have been around twenty percent, the intensity of intra-BRICS exports, imports and total trade decreased during 2001-15. One possible reason for it that has come out of the study is that during 2001-2015, total world trade with BRICS as a ratio of total world trade increased at a faster rate (6.31) than the total intra -BRICS trade as a ratio of total BRICS trade from World(5.11).

Further, the findings of the present study also reveals the fact that although 17 percent of world trade is accounted by BRICS but so far as trade among BRICS countries is concerned, intra-BRICS trade is just 12.12 percent of total BRICS trade with the world. Intra-BRICS trade of major BRICS countries (China, India and Russia) became less intense as intra-BRICS trade intensities decreased in 2015 compared to that in 2001. For India and Russia it is 0.84 and 0.84 respectively and for China, it is just 0.59 in 2015, implying that China's trade with other BRICS countries is far less than expected, given its importance in world trade. However for Brazil and South Africa, trade flows between these two countries and other BRICS countries is more than expected given their importance in world trade, as the figures for intra-BRICS trade intensity are greater than one.

\section{LIMITATIONS OF THE STUDY ANDSCOPE FOR FURTHER RESEARCH}

The analysis of intra BRICS trade intensities done in the study focuses on trade in commodities only and hence trade in services has not been included. Since service sector accounted for more than 50 percent of GDP in all BRICS countries except China in 2014 [20], in future researches, focus may be widened by also including trade in services.Besides, in order to assess future prospects of intra BRICS trade for each member country, trade complementarity indices can be calculated.

\section{REFERENCES}

[1] Singh, Kalpana. A Comparative Analysis of Foreign Trade of BRICS Countries. Prabandhan: Indian Journal of Management, p. 29-40, feb. 2016. Retrieved from <http://www.indianjournalofmanagement.com/index.php/pijom/article/view/87235>. Date accessed: 25 Apr. 2016. doi:10.17010/pijom/2016/v9i2/87235.

[2] Information about BRICS. (n.d., para.2). Retrieved from http://brics.itamaraty.gov.br/aboutbrics/information-about-brics

[3] The Economist (2013). Why is South Africa included in the BRICS? March 29. Retrieved August 5, 2015 from www.economist.com/blogs/.../economist-explains-why-south-africa-brics

[4] India to host 8th BRICS Summit in Goa.(2016,March,22). The Hindu. Retrieved from http://www.thehindu.com/news/national/india-to-host-8th-brics-summit-in-goa/article8385272.Ece

[5] Andrey Movchan(2015). 5 factors limiting the impact of the BRICS nations. World Economic Forum.July 8.Retrieved on April 26,2016 from https://www.weforum.org/agenda/2015/07/5-factorslimiting-the-impact-of-the-brics-nations/

[6] BRICS establish \$100bn bank and currency pool to cut out Western dominance (2015, July 15). RT. Retrieved from https://www.rt.com/business/173008-brics-bank-currency-pool/

[7] Mathur, S. and DasGupta, M.(Eds) (2013). BRICS Trade Policies, Institutions and Areas for Deepening Cooperation. Indian Institute of Foreign Trade (IIFT). March. Retrieved August 5, 2015 from wtocentre.iift.ac.in/FA/Brics.pdf

[8] dr MORAZÁN, Pedro, KNOKE, Irene, KNOBLAUCH, Doris \& SCHÄFER, Thobias (2012).The Role of BRICS in the Developing World. Policy Department, European Parliament. Retrieved April 27,2016 from http://ecologic.eu/sites/files/project/2013/knoblauch_12_lot5_24_brics.pdf

[9] The Global Diplomatic Forum (2015).The BRICS Forum: The Evolving Role of the BRICS in a changing world. April 28. Retrieved August 15, 2015 from www.gdforum.org/balkanssecurity-2-2/

[10] The BRICS bank An acronym with capital (2014, Jul 19). The Economist. Retrieved from http://www.economist.com/news/finance-and-economics/21607851-setting-up-rivals-imf-and-worldbank-easier-running-them-acronym\#

[11] "The Strategy For Brics Economic Partnership",n.d. Retrieved May 1,2016 from www.brics.mid.ru/bdomp/brics.nsf/Ufa_partnershipstrategy_eng.pdf 
[12] Maxwell Ekor, Jimoh Saka and Oluwatosin Adeniyi(2015). Trade Intensity Analysis of South AfricaBRIC Economic Relations.Eastern Africa Social Science Research Review Volume 31, Number 2, June.pp. 1-34 .Retrieved May 1,2016 from https://muse.jhu.edu/article/588812

[13] PradumnaBickram Rana a ,Tianyin Cheng b and Wai-Mun Chia b (2012). 'Trade intensity and business cycle synchronization: East Asia versus Europe' Journal of Asian Economics. Volume 23, Issue 6, pp 701-706.December. retrieved May 2,2016 from http://www.waseda.jp/gsaps /eaui/educational_program/PDF3/Reading2_NTU_Chia\%20Wai\%20Mun_Rana\%20et\%20al\%20\%20JAE\%20-\%202012b.p

[14] PradeepaDembatapitiya(2013). Case Study: Trade Flow And Determinants Of Trade Intensity In South Asian Region. United Nations Economic and Social Commission for Asia and the Pacific. November 18.Retrieved May 3,2016 from http://artnet.unescap.org/tid/projects/aftdialogue-pradeepa.pdf

[15] Silva, Valquiria da, Anefalos, Lilian C., \& R. Filho, José Carlos G. dos. (2003). Relative intensity of bilateral trade flows, regional integration, and trade performance: the case of Brazil, 1984-1998. Revista de Economia e Sociologia Rural, 41(2), 345-360. https://dx.doi.org/10.1590/S010320032003000200002.Retrieved May 4 from http://www.scielo.br/scielo.php?script=sci_ arttext\&pid=S0103-20032003000200002\#

[16] Integration Indicators technical notes(n.d.). Asia Regional Integration Center.Retrieved fromhttps://aric.adb.org/integrationindic

[17] International Trade Centre. Trade by Commodity Statistics 2001-2015. Retrieved April 25, 2016 from www.intracen.org/itc/market-info-tools/trade-statistics/

[18] Charles A. Kupchan.(2012).The World in 2050: When the 5 Largest Economies Are the BRICs and Us. The Atlantic.February,17.Retrieved from http://www.theatlantic.com/business/archive/2012/02/theworld-in-2050-when-the-5-largest-economies-are-the-brics-and-us/253160/

[19] Ritesh K. Singh(2012). Scope to improve intra-BRICS trade. April 3. Business Line. Retrieved June 9,2016 from http://www.thehindubusinessline.com/opinion/scope-to-improve-intrabricstrade/article3277587.ece

[20] The World Bank.Services, etc., value added (\% of GDP). Retrieved from http://data.worldbank.org/indicator/NV.SRV.TETC.ZS

\section{Annexure-IBRICS' countries percentage share in world Exports, imports and total world} Trade $(\mathrm{X}+\mathrm{M})$

\begin{tabular}{|c|c|c|c|c|c|c|c|c|c|c|c|c|c|c|c|}
\hline \multirow{2}{*}{ Year } & \multicolumn{4}{|c|}{ Share in world Exprts } & \multicolumn{4}{|c|}{ Share in world Imports } & \multicolumn{4}{c|}{ Share in Total world Trade } \\
\cline { 2 - 16 } & India & China & Brazil & Russia & S.Africa & India & China & Brazil & Russia & S.Africa & India & China & Brazil & Russia & S.Africa \\
\hline 2001 & 0.72 & 4.35 & 0.95 & 1.63 & 0.43 & 0.80 & 3.85 & 0.88 & 0.66 & 0.40 & 0.76 & 4.10 & 0.92 & 1.14 & 0.41 \\
\hline 2002 & 0.78 & 5.08 & 0.94 & 1.67 & 0.36 & 0.87 & 4.48 & 0.72 & 0.70 & 0.40 & 0.83 & 4.78 & 0.83 & 1.18 & 0.38 \\
\hline 2003 & 0.80 & 5.87 & 0.98 & 1.79 & 0.42 & 0.94 & 5.37 & 0.63 & 0.75 & 0.45 & 0.87 & 5.62 & 0.80 & 1.26 & 0.44 \\
\hline 2004 & 0.84 & 6.53 & 1.06 & 2.00 & 0.44 & 1.05 & 5.98 & 0.67 & 0.81 & 0.51 & 0.95 & 6.25 & 0.86 & 1.39 & 0.48 \\
\hline 2005 & 0.97 & 7.37 & 1.15 & 2.33 & 0.45 & 1.33 & 6.22 & 0.69 & 0.93 & 0.52 & 1.15 & 6.79 & 0.92 & 1.62 & 0.49 \\
\hline 2006 & 1.01 & 8.11 & 1.15 & 2.52 & 0.44 & 1.46 & 6.46 & 0.75 & 1.13 & 0.56 & 1.24 & 7.27 & 0.95 & 1.82 & 0.50 \\
\hline 2007 & 1.06 & 8.86 & 1.17 & 2.56 & 0.46 & 1.55 & 6.78 & 0.86 & 1.42 & 0.57 & 1.31 & 7.81 & 1.01 & 1.98 & 0.52 \\
\hline 2008 & 1.14 & 8.96 & 1.24 & 2.93 & 0.46 & 1.93 & 6.93 & 1.06 & 1.63 & 0.54 & 1.54 & 7.93 & 1.15 & 2.27 & 0.50 \\
\hline 2009 & 1.44 & 9.76 & 1.24 & 2.45 & 0.44 & 2.11 & 7.98 & 1.01 & 1.36 & 0.51 & 1.78 & 8.86 & 1.13 & 1.90 & 0.47 \\
\hline 2010 & 1.46 & 10.48 & 1.31 & 2.64 & 0.55 & 2.29 & 9.12 & 1.18 & 1.50 & 0.54 & 1.88 & 9.79 & 1.24 & 2.06 & 0.55 \\
\hline 2011 & 1.65 & 10.42 & 1.40 & 2.84 & 0.59 & 2.51 & 9.45 & 1.23 & 1.66 & 0.56 & 2.08 & 9.93 & 1.32 & 2.24 & 0.57 \\
\hline 2012 & 1.57 & 11.10 & 1.31 & 2.84 & 0.54 & 2.63 & 9.78 & 1.20 & 1.70 & 0.56 & 2.10 & 10.43 & 1.26 & 2.27 & 0.55 \\
\hline 2013 & 1.78 & 11.67 & 1.28 & 2.79 & 0.50 & 2.46 & 10.29 & 1.26 & 1.66 & 0.55 & 2.12 & 10.98 & 1.27 & 2.22 & 0.52 \\
\hline 2014 & 1.67 & 12.34 & 1.19 & 2.62 & 0.48 & 2.41 & 10.29 & 1.20 & 1.51 & 0.52 & 2.04 & 11.31 & 1.19 & 2.06 & 0.50 \\
\hline 2015 & 1.62 & 13.97 & 1.17 & 2.04 & 0.50 & 2.37 & 10.20 & 1.04 & 1.08 & 0.52 & 2.00 & 12.08 & 1.11 & 1.56 & 0.51 \\
\hline
\end{tabular}

Source: Compiled and Computed by the author based on International Trade Centre, (ITC) database, Trade by Commodity Statistics 2001-2015[17] 
Annexure-II Intra-BRICS Trade intensity indices of BRICS countries

\begin{tabular}{|c|c|c|c|c|c|c|c|c|c|c|c|c|c|c|c|}
\hline \multirow{2}{*}{ Year } & \multicolumn{5}{|c|}{ Export Intensity Index (XII) } & \multicolumn{5}{|c|}{ Import Intensity Index (MII) } & \multicolumn{5}{|c|}{ Trade Intensity Index (III) } \\
\hline & India & China & Brazil & Russia & S.Africa & India & China & Brazil & Russia & S.Africa & India & China & Brazil & Russia & S.Africa \\
\hline 2001 & 0.77 & 0.39 & 0.93 & 1.01 & 0.64 & 1.01 & 1.15 & 0.62 & 0.98 & 1.02 & 0.91 & 0.78 & 0.77 & 0.97 & 0.84 \\
\hline 2002 & 0.84 & 0.37 & 1.10 & 1.11 & 0.60 & 1.11 & 1.18 & 0.69 & 1.09 & 1.03 & 1.00 & 0.78 & 0.89 & 1.07 & 0.85 \\
\hline 2003 & 0.83 & 0.37 & 1.19 & 1.01 & 0.57 & 0.96 & 1.18 & 0.76 & 1.00 & 1.08 & 0.91 & 0.79 & 0.99 & 0.98 & 0.86 \\
\hline 2004 & 0.87 & 0.39 & 0.98 & 0.77 & 0.52 & 0.93 & 1.19 & 0.83 & 0.87 & 1.06 & 0.91 & 0.80 & 0.90 & 0.78 & 0.83 \\
\hline 2005 & 1.03 & 0.41 & 1.04 & 0.67 & 0.63 & 0.94 & 1.19 & 0.88 & 0.89 & 1.13 & 0.98 & 0.80 & 0.95 & 0.71 & 0.93 \\
\hline 2006 & 0.95 & 0.42 & 0.98 & 0.61 & 0.61 & 0.91 & 1.16 & 0.93 & 0.96 & 1.19 & 0.94 & 0.78 & 0.93 & 0.70 & 0.98 \\
\hline 2007 & 0.87 & 0.51 & 0.94 & 0.48 & 0.85 & 1.04 & 1.10 & 1.03 & 1.09 & 1.14 & 0.99 & 0.79 & 0.97 & 0.71 & 1.03 \\
\hline 2008 & 0.75 & 0.52 & 0.98 & 0.49 & 0.82 & 0.94 & 1.08 & 1.12 & 1.08 & 1.16 & 0.90 & 0.78 & 1.04 & 0.71 & 1.02 \\
\hline 2009 & 0.64 & 0.43 & 1.37 & 0.60 & 1.16 & 1.05 & 1.05 & 1.05 & 1.10 & 1.24 & 0.91 & 0.73 & 1.21 & 0.78 & 1.21 \\
\hline 2010 & 0.80 & 0.45 & 1.35 & 0.46 & 0.99 & 0.97 & 0.92 & 1.14 & 1.23 & 1.20 & 0.92 & 0.68 & 1.24 & 0.75 & 1.10 \\
\hline 2011 & 0.60 & 0.45 & 1.34 & 0.52 & 1.01 & 0.94 & 0.93 & 1.15 & 1.09 & 1.19 & 0.82 & 0.69 & 1.24 & 0.73 & 1.10 \\
\hline 2012 & 0.61 & 0.43 & 1.33 & 0.55 & 0.97 & 0.86 & 0.97 & 1.12 & 1.08 & 1.20 & 0.77 & 0.69 & 1.22 & 0.75 & 1.09 \\
\hline 2013 & 0.56 & 0.42 & 1.37 & 0.52 & 1.04 & 0.79 & 0.90 & 1.09 & 1.07 & 1.27 & 0.71 & 0.66 & 1.22 & 0.73 & 1.17 \\
\hline 2014 & 0.56 & 0.42 & 1.40 & 0.56 & 0.93 & 0.88 & 0.84 & 1.14 & 1.12 & 1.21 & 0.77 & 0.62 & 1.26 & 0.77 & 1.09 \\
\hline 2015 & 0.45 & 0.39 & 1.47 & 0.68 & 0.93 & 1.02 & 0.83 & 1.15 & 1.17 & 1.34 & 0.84 & 0.59 & 1.29 & 0.85 & 1.17 \\
\hline
\end{tabular}

Source: Compiled and Computed by the author based on International Trade Centre, (ITC) database, Trade by Commodity Statistics 2001-2015[17] 